\title{
Mapping and Characterization of Mutants of Pseudomonas aeruginosa Affected in Nitrate Respiration in Aerobic or Anaerobic Growth
}

\author{
By J. VAN HARTINGSVELDT AND A. H. STOUTHAMER \\ Microbiology Department, Biological Laboratory, Free University, \\ De Boelelaan 1087, Amsterdam, The Netherlands
}

(Received 3I January 1972; revised 25 August 1972)

\begin{abstract}
SUMMA R Y
Genes which are involved in anaerobic growth with nitrate or nitrite as terminal electron acceptor in Pseudomonas aeruginosa were mapped by interrupted mating and linkage analysis after conjugation. Times of entry were mostly consistent with the linkage frequencies. Late markers were not located precisely. A gene order was obtained for the genes involved in dissimilatory nitrate (nar) and nitrite reduction (nir) and anaerobical growth (ana) and for some already known auxotrophic genes. A mutant unable to grow aerobically (aer) was found. The aer mutation appeared to be an early marker. The cytochrome spectra of nir mutants and part of the cytochrome oxidase activities were abnormal in that haem $d$ was absent. Most of the nar mutants were pleiotropic. NarA mutants were affected in assimilatory and dissimilatory nitrate reductase, and $\operatorname{nar} B$, nar $D$ and $\operatorname{nar} E$ mutants lacked assimilatory and dissimilatory nitrate reductase and xanthine dehydrogenase. In nar $D$ mutants high concentrations of molybdate restored xanthine dehydrogenase and assimilatory and dissimilatory nitrate reductase and, consequently, anaerobic growth. Just as in the aer mutants, which had a normal respiratory system, the denitrifying system and the cytochrome system in ana mutants were normal. It is therefore unlikely that ana and aer mutants synthesize defective energy generating systems.
\end{abstract}

\section{INTRODUCTION}

Nitrate respiration has been shown to be an important process in Pseudomonas aeruginosa. It is the only way in which anaerobic growth occurs (Yamanaka, Ota \& Okunuki, I96I). Pseudomonas aeruginosa is one of the most important denitrifying organisms in grassland soils (Woldendorp, I963). Under anaerobic conditions it is responsible for the loss of utilizable nitrogen as it can form free nitrogen from nitrate. Stanier, Palleroni \& Douderoff (I966) reported denitrification as a good taxonomic character to differentiate aerobic pseudomonads. Therefore it seemed of interest to know something of the genetical aspects of nitrate dissimilation. Mutants, defective in anaerobic growth in the presence of nitrate, have been isolated. They have been shown to belong to three groups. Mutants of the first (nar) lack nitrate reductase A, those of the second (nir) lack nitrite reductase, and those of the third (ana) are normal in nitrate and nitrite dissimilation but still altered in anaerobic growth (van Hartingsveldt, Marinus \& Stouthamer, I97 I). Each of these groups appeared to consist of mutants of several genes, some of which have been mapped by recombination and interrupted mating analysis.

Studies of mutants unable to grow aerobically (aer) have yielded information on the differences between the aerobic and anaerobic respiration systems.

The nar mutants showed some similarities to the chl mutants of Escherichia coli, in that they are chlorate resistant and most of them are pleiotropic mutants (Piéchaud et al. 1967). 
Lester \& DeMoss (I97I) reported a molybdate stimulation of nitrate reductase activity in $E$. coli. High concentrations of molybdate can restore nitrate reductase activity in some chlD mutants of $E$. coli (Glaser \& DeMoss, 197I) and also in some mutants of Aspergillus nidulans (Arst, MacDonald \& Cove, I970). A similar effect has been sought in one of the nar mutants of Pseudomonas aeruginosa.

As the nitrite reductase of Pseudomonas aeruginosa is a haemoprotein with cytochrome oxidase activity, containing a haem $c$ and a haem $d$ group (Yamanaka \& Okunuki, 1963), cytochrome spectra have been recorded and cytochrome oxidase activities determined, to detect possible differences between the nir mutants.

\section{METHODS}

Bacterial strains and bacteriophage. Most of the bacterial strains of Pseudomonas aeruginosa (Table I) have been described (van Hartingsveldt et al. 197I). NarE mutants were isolated as chlorate resistant strains from strain SI073 FP- ilvBII2 his-6 leu-I str and aer mutants by treating strain $\mathrm{s} 840 \mathrm{FP}^{-}$met-28 trp-6 with $N$-methyl- $N^{\prime}$-nitro- $N$-nitrosoguanidine as described by van Hartingsveldt et al. (I97I). The transducing bacteriophage was FII6 (Holloway, Monk, Hodgins \& Fargie, 1962).

Media, culture procedures, conjugation, transduction and preparation of cell-free extracts. These were as described by van Hartingsveldt et al. (197I).

Incubation under low oxygen tension. Plates were incubated in anaerobic jars, which had been evacuated partially to $10,7,4$ or $2 \%$ of the air pressure and refilled with nitrogen to a pressure of $\mathrm{I}$ atmosphere.

Mapping by time of entry. Logarithmic-phase donor and stationary-phase acceptor suspensions at about $5 \times 10^{8}$ bacteria/ml in nutrient broth (NB) $+0.5 \% \mathrm{KNO}_{3}$ were mixed at $37^{\circ} \mathrm{C}$ and left to pair for $5 \mathrm{~min}$. They were gently diluted $10^{-2}$ in fresh $\mathrm{NB}+\mathrm{KNO}_{3}$ at $37^{\circ} \mathrm{C}$. Samples were removed at $5 \mathrm{~min}$ intervals, shaken on a Vortex Genie Mixer for I min to separate the pairs, concentrated tenfold in the presence of streptomycin and plated, undiluted or diluted $10^{-1}$, on selective medium. The streptomycin sensitivity and auxotrophy of donor bacteria ensured contra-selection. For late markers dilution and concentration were omitted.

Enzyme assays and cytochrome spectra. In cell-free extracts nitrate reductase activity was measured as described by Van'T Riet, Stouthamer \& Planta (1968). Specific activity is expressed as $\mu \mathrm{mol}$ nitrite produced $/ \mathrm{min} / \mathrm{mg}$ protein. Protein was estimated according to Lowry, Rosebrough, Farr \& Randall (I95I). In cell-free extracts cytochrome oxidase activity was measured by a manometric technique (Umbreit, Burris \& Stauffer, I964). Endogenous cytochrome $c$, reduced by sodium ascorbate, was used as substrate. Specific activity is expressed as $\mathrm{nmol} \mathrm{O}_{2}$ consumed/min/mg protein. $\mathrm{NADH}$-oxidase activity was measured in a Unicam SP 800 spectrophotometer with I cm light-path quartz cuvettes, by following the rate of oxidation of reduced NADH. The system contained $400 \mu \mathrm{g} \mathrm{NADH}$ and 0.1 or $0.2 \mathrm{ml}$ cell-free extract with a total of 5 to $10 \mathrm{mg}$ protein in $3 \mathrm{ml} 0.025 \mathrm{M}$-potassium phosphate buffer, $\mathrm{pH} 7 \cdot 0$. Activity is expressed as nmol NADH oxidized $/ \mathrm{min} / \mathrm{mg}$ protein. The molar extinction coefficient of NADH is $6.2 \times 10^{3} \mathrm{M}^{-1} \mathrm{~cm}^{-1}$ at $340 \mathrm{~nm}$. Oxygen uptake was measured for whole resting bacteria, using standard Warburg techniques.

Stationary-phase bacteria semi-anaerobically grown in $\mathrm{NB}+\mathrm{KNO}_{3}$ were washed twice in cold $0.065 \mathrm{M}$-phosphate buffer, $\mathrm{pH} 7 \cdot 2$, and resuspended in about $\mathrm{I} / 40$ of the initial volume in the same buffer. In these bacterial suspensions spectra of cytochromes (reduced minus oxidized) were recorded at room temperature in I cm light-path glass cuvettes in an Aminco 
Table I. Genetic characteristics of the strains of Pseudomonas aeruginosa used in the investigation

\begin{tabular}{|c|c|c|}
\hline Strain number & Characteristics & Origin \\
\hline $\mathrm{s} 838$ & FP- $s t r$ & . \\
\hline$s 840$ & $\mathrm{FP}^{-}$met -28 trp-6 & . \\
\hline s84I & $\mathrm{FP}^{+} \operatorname{trp}-6$ & $\cdot$ \\
\hline s925 & $\mathrm{FP}^{-}$met-28 trp-6 nir $A$ & $s 840$ \\
\hline sio62 & $\mathrm{FP}^{-}$met-28 trp-6 anaB & $s 840$ \\
\hline sio68 & $\mathrm{FP}^{-}$met-28 trp-6 leu str nir $A$ & s840 \\
\hline SIO73 & FP- ilvBII2 his-6 leu-I str & . \\
\hline 51074 & FP- ilvBII 2 met-9 leu-I str & . \\
\hline SI 125 & FP- met-28 trp-6 ana $A$ & s840 \\
\hline SI 128 & $\mathrm{FP}^{-}$nar B str & s838 \\
\hline $\operatorname{SII} 30$ & $\mathrm{FP}^{-}$narA str & s838 \\
\hline SI 133 & $\mathrm{FP}^{-}$narC str & s838 \\
\hline SII35 & $\mathrm{FP}^{-}$nar $B$ str & $\mathrm{s} 838$ \\
\hline S1229 & FP- ilvBri2 met-9 leu-I str nar $A$ & SIO74 \\
\hline SI 230 & FP- ilvBri2 met-9 leu-I str nar A & s1074 \\
\hline SI $23 I$ & FP- ilvBII 2 met-9 leu-I str narB & $\mathrm{SIO} 74$ \\
\hline SI 232 & $\mathrm{FP}^{-}$ilvBII 2 met-9 leu-I str narC & sio74 \\
\hline SI 233 & FP- ilvBII 2 met-9 leu-I str narC & $\mathrm{sio74}$ \\
\hline SI 234 & FP- ilvBII2 met-9 leu-I str narD & $\mathrm{SIO} 74$ \\
\hline SI 235 & FP- ilvBII 2 met-9 leu-I str narD & SI074 \\
\hline SI 239 & FP- ilvBII 2 met-9 leu-I str nirD & S1074 \\
\hline SI 240 & FP- ilvBII2 met-9 leu-I str nirE & SI074 \\
\hline SI 24 I & FP- ilvBII2 his-6 leu-I str narE thi & s 1073 \\
\hline SI 275 & FP- met-28 trp-6 str nic aer & s840 \\
\hline SI 276 & $\mathrm{FP}^{-}$met-28 trp-6 str nic aer & $s 840$ \\
\hline SI $40 I$ & FP- ilvBII2 his-6 leu-I str narE thi & S 1073 \\
\hline
\end{tabular}

$a e r$, No aerobic growth; ana, affected in anaerobic growth; his, histidine requirement; ilv, isoleucine + valine requirements; leu, leucine requirement; met, methionine requirement; nar, no dissimilatory nitrate reductase activity; nic, nicotinic acid requirements; nir, no dissimilatory nitrite reductase activity; str, streptomycin resistance; thi, thiamin requirement; trp, tryptophan requirement.

Chance Duochromator spectrophotometer. Reduction was achieved by adding small amounts of sodium dithionite, and oxidation by adding nitrate $(40 \mathrm{~mm})$ or nitrite $(40 \mathrm{~mm})$ to the bacterial suspensions or by bubbling through oxygen.

\section{RESULTS}

New mutants. Among the strains used in this work (Table I) two mutants, SI 24I and SI 40I were isolated which did not utilize nitrate under anaerobic conditions and simultaneously developed a thiamin requirement. These nar mutants belonged to the same transduction group which was located away from the $\operatorname{nar} A, B, C$ and $D$ genes; they were designated nar $E$. The two aer mutants, SI275 and SI276, were auxotrophic for nicotinic acid (nic) and they too belonged to one transduction group.

Mapping by linkage analysis. From mating experiments the linkage frequencies of different markers with the nar mutants were determined (Table 2). In strain SI 230 nar $A$ was not linked with the early markers $i l v B I I 2$ and met-9 (Loutit, 1969) and only 2 or $3 \%$ linked with the late marker leu-I. Nar A was not linked with met-28 and trp-6 (van Hartingsveldt et al. 197I). Therefore nar $A$ must be located distally from leu-I (Fig. I). $\mathrm{NarB}^{+}$and $n a r C^{+}$recombinants (strain SI23I and SI232) on the contrary had a high recovery of $l e u-I^{+} ; l e u-I^{+}$recombinants showed a lower recovery of $\operatorname{nar} B^{+}$than of $\operatorname{nar} C^{+}$. Therefore $\operatorname{nar} B$ must be situated more distally from leu-I than $\operatorname{nar} C$. In strain SI 234 the nar $D$ marker was unlinked to any of the 
Table 2. Percentage linkage of unselected and selected markers in the nar mutants of Pseudomonas aeruginosa after mating with strain $\mathrm{SI}$ I $4 \mathrm{I}$ or $\mathrm{S} 84 \mathrm{I}$

Two hundred colonies were screened in each cross.

\begin{tabular}{|c|c|c|c|c|c|c|}
\hline \multirow[b]{2}{*}{ Recipient } & \multicolumn{5}{|c|}{ Selected markers } & \multirow{2}{*}{$\begin{array}{l}\text { Unselected } \\
\text { markers }\end{array}$} \\
\hline & $i l v B I I 2^{+}$ & $m e t-9^{+}$ & $h i s-6^{+}$ & leu-I ${ }^{+}$ & $n a r^{+}$ & \\
\hline \multirow[t]{2}{*}{ SI230 nar $A$} & n.d. & n.d. & . & . & 3 & $\operatorname{leu}-\mathrm{I}^{+}$ \\
\hline & 0 & 0 & . & 2 & & $\operatorname{nar} A^{+}$ \\
\hline \multirow[t]{2}{*}{ SI23I nar $B$} & n.d. & n.d. & . & $\dot{0}$ & 38 & leu- $-I^{+}$ \\
\hline & 0 & 0 & . & 26 & & $\operatorname{nar} B^{+}$ \\
\hline \multirow[t]{2}{*}{ SI $232 \operatorname{nar} C$} & n.d. & n.d. & . & . & 50 & $l e u-I^{+}$ \\
\hline & 0 & 0 & . & 35 & . & $\operatorname{nar} C^{+}$ \\
\hline \multirow[t]{2}{*}{ SI 234 nar D } & 0 & 0 & . & 0 & . & $\operatorname{nar} D^{+}$ \\
\hline & & & 33 & n.d. & & narE $E^{-}$ \\
\hline \multirow{2}{*}{ SI24I narE } & & n.d. & n.d. & n.d. & 60 & ilvBII2+ \\
\hline & n.d. & n.d. & . & n.d. & 10 & his $-6^{+}$ \\
\hline
\end{tabular}

auxotrophic markers used. With the narE mutants no $i l v^{+}$recombinants could be selected as isoleucine and valine are not required with addition of thiamin to the minimal medium, as Loutit \& Davis (1970) observed for some of their ilvB mutants.

Since all $n a r E^{+}$recombinants lost the requirement for thiamin, however, close linkage of narE and ilvBII 2 could be demonstrated by using minimal medium without thiamin. Linkage of narE and his-6 was much lower. NarE must be proximal to his-6 (Fig. I).

The linkage data for the aer mutants, SI 275 and S1276 (Table 3), demonstrated that aer is proximal to met-28. This observation and the relatively great number of recombinants in conjugation (about $10^{-5} /$ acceptor bacterium) suggest that aer is an early gene. No met $t^{+}$and $\operatorname{trp}^{+}$recombinants could be obtained to confirm this. Selection of $n i c^{+}$recombinants did not result in recovery of $a e r^{+}, m e t-28^{+}$or $\operatorname{trp}-6^{+}$, and therefore the nicotinic acid requirement must be due to a secondary mutation located away from these three genes.

Mapping by interrupted mating. In contrast to the distal nar $A$ and narD genes, leu-I, nar $B$, $C$ and $E$ could be mapped easily by interrupted mating (Table 4 ). The distal leu-I marker (Loutit, 1969) and narB and narC entered at about $45 \mathrm{~min}$ and narE at $9 \mathrm{~min}$. This is in accordance with the close linkage of $\operatorname{nar} B$ and $n a r C$ to leu-I and of narE to ilvBII2. The times of entry of nar $A$ and narD were very late and consequently not very precise. The results obtained with the reference markers met-28, trp-6 and ilvBII2 differed at most by 2 min from the data of Loutit (1969) and Stanisich \& Holloway (1969).

For some unknown reason strain 5925 did not give nir $^{+}$recombinants in interrupted mating so that no entry time could be determined. At any time from the moment of entry of $m e t-28^{+}$, about $55 \%$ of the met $^{+}$recombinants were nir $A^{+}$. Evidently, nir $A^{+}$entered prior to $m e t-28^{+}$, as was proposed in our previous paper (van Hartingsveldt et al. I97I). NirD and nirE appeared to be late markers.

Strains SII 25 and SIO62 (formerly nir $B$ and nirC) did not lack nitrite reductase activity, but were still affected in anaerobic growth. They were thus designated ana $A$ and ana $B$. Mapping of the ana and aer genes by interrupted mating was impossible. Transduction revealed that anaA (formerly nir $B$ ) was located between $m e t-28$ and $\operatorname{trp}-6$ (van Hartingsveldt et al. 1971).

Transduction. NarB and leu-I, narC and leu-I and narE and $i l v B I I 2$ were not co-transducible by phage Fi 6. 
Table 3. Percentage linkage of selected and unselected markers of Pseudomonas aeruginosa after mating of aer mutants with strain $\mathrm{SI} 4 \mathrm{I}$

Two hundred recombinants were screened in each cross.

\begin{tabular}{|c|c|c|c|}
\hline \multirow[b]{2}{*}{ Recipient } & \multicolumn{2}{|c|}{ Markers } & \multirow{2}{*}{$\begin{array}{c}\text { Double } \\
\text { recombinants } \\
(\%)\end{array}$} \\
\hline & Selected & Unselected & \\
\hline \multirow[t]{6}{*}{ SI 275} & $a e r^{+}$ & $m e t-28^{+}$ & I I \\
\hline & & $\operatorname{trp}-6^{+}$ & 2 \\
\hline & & $n i c^{+}$ & 0 \\
\hline & $n i c^{+}$ & $m e t-28^{+}$ & 0 \\
\hline & & $\operatorname{trp}-6^{+}$ & 0 \\
\hline & & $\mathrm{aer}^{+}$ & 0 \\
\hline \multirow[t]{3}{*}{ SI 276} & $a e r^{+}$ & $m e t-28^{+}$ & IO \\
\hline & & $\operatorname{trp}-6^{+}$ & 3 \\
\hline & & $n_{i c}^{+}$ & 0 \\
\hline
\end{tabular}

Table 4. Time of entry of some nar and nir genes and some reference markers in interrupted mating of Pseudomonas aeruginosa

$\begin{array}{clc}\text { Recipient } & \text { Marker } & \begin{array}{c}\text { Time of entry } \\ \text { (min) }\end{array} \\ \text { S840 } & \text { met-28 } & 29 \\ \text { S840 } & \text { trp-6 } & 3 \mathrm{I} \\ \text { SIO68 } & \text { nirA } & <29 \\ \text { SI073 } & \text { leu-I } & 44 \\ \text { SII28 } & \text { narB } & 44 \\ \text { SI230 } & \text { narA } & 65 \\ \text { SI232 } & \text { ilvBII2 } & 7 \\ \text { SI232 } & \text { narC } & 45 \\ \text { SI234 } & \text { narD } & 65 \\ \text { SI239 } & \text { nirD } & 70 \\ \text { SI240 } & \text { nirE } & 70 \\ \text { SI24I } & \text { narE } & 9\end{array}$

Linkage map. From these data and from those of Loutit (1969), Stanisich \& Holloway (I969) and van Hartingsveldt et al. (1971) a linkage map was constructed (Fig. I). Loutit proposed two linkage groups (I and II) in Pseudomonas aeruginosa. Linkage between markers of these groups has not been demonstrated. The late genes $\operatorname{nar} A$, nar $D$, nir $D$ and $\operatorname{nir} E$ might belong either to group I or II. The positions of aer, nic and anaB are not given in this map. Aer is most probably in linkage group II and nic in group I.

Pleiotropic effects in nar mutants and the influence of molybdate. Nitrate reductase in Pseudomonas aeruginosa contains molybdenum (Fewson \& Nicholas, 196I) so possibly some of our mutants might form an inactive enzyme complex without molybdenum as Glaser \& DeMoss (197I) observed in chlD mutants of Escherichia coli. The addition of high concentrations of molybdate $\left(5 \times \mathrm{IO}^{-4} \mathrm{M}\right)$ restored nitrate reductase and formate hydrogenlyase activities in these $\operatorname{chl} D$ mutants. Only the nar $D$ strains of $P$. aeruginosa regained the ability to grow under anaerobic conditions in the presence of nitrate and $5 \times 10^{-4} \mathrm{M}$-sodium molybdate. Cell-free extracts of nar $D$ mutants grown overnight in the presence of molybdate had a nitrate reductase activity of about $70 \%$ of that of the wild-type (Table 5).

In some Aspergillus nidulans mutants, which lack both nitrate reductase and xanthine dehydrogenase activity (Pateman, Cove, Rever \& Roberts, I964), these activities could be restored by adding high concentrations of molybdate to the culture medium (Arst et al. 1970). It was proposed that nitrate reductase and xanthine dehydrogenase shared a molyb- 

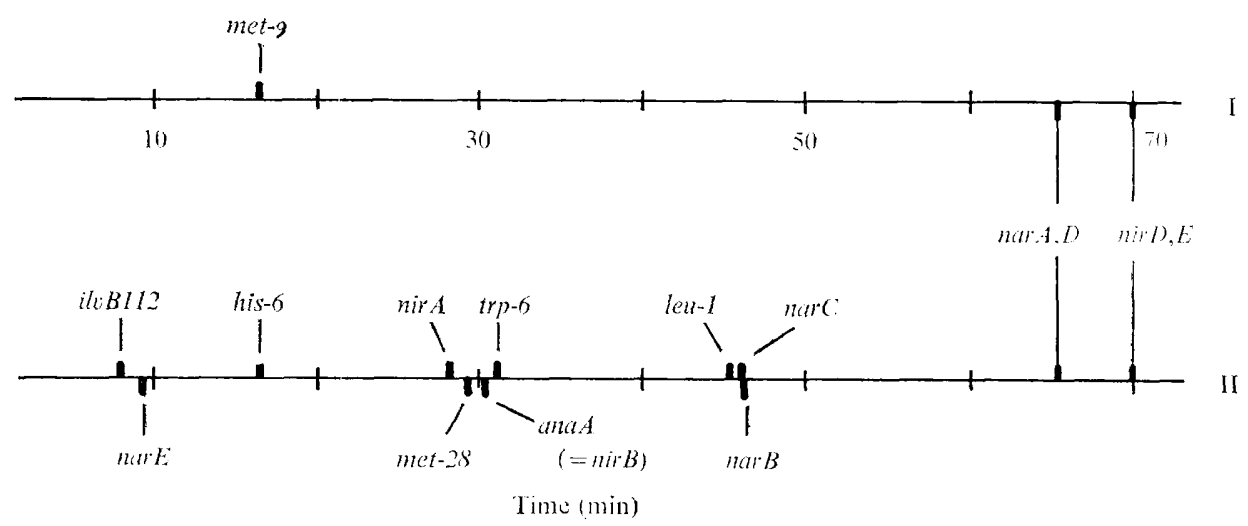

Fig. I. Location of some nir and nar genes on the maps of the two linkage groups ( 1 and II) of Pseudomonas aeruginosa. Gene symbols as in Table I.

denum-containing co-factor. In Neurospora crassa Ketchum, Cambier, Frazier, Madansky \& Nason (I970) could restore NADPH-nitrate reductase activity in cell-free extracts of mutants lacking nitrate reductase and xanthine dehydrogenase by adding mammalian xanthine oxidase or chicken-liver xanthine dehydrogenase to the extracts at low $\mathrm{pH}$.

In view of these results it seemed interesting to test our nar mutants for the use of hypoxanthine or nitrate as sole nitrogen sources. A number of these mutants appeared to grow with the amino acids, for which they are auxotrophic. In such cases prototrophic recombinants, obtained in conjugation experiments, were used in the growth experiments. Nar $B$, $D$ and $E$ strains were unable to assimilate nitrate or hypoxanthine (Table 6). Nar $A$ lacks only the ability to assimilate nitrate. As nar ${ }^{+}$recombinants or revertants were also restored in the assimilation of nitrate and hypoxanthine, $\operatorname{nar} B$ and $\operatorname{nar} D$ were likely to be pleiotropic mutations, affected in both assimilatory and dissimilatory nitrate reduction and degradation of hypoxanthine, and narA to be a pleiotropic mutation, affected only in assimilatory and dissimilatory nitrate reduction. From nar $E$ mutants three types of recombinants were isolated in conjugation experiments. In the first the defects in nitrate reductase and degradation of hypoxanthine were restored; in the second the ability to assimilate nitrite was regained; and in the third both defects were overcome. Therefore the narE mutants must have two mutations: narE causing defects in assimilatory and dissimilatory nitrate reductase and in hypoxanthine degradation, and another resulting in the loss of assimilation of nitrite. Only in nar $D$ mutants could the use of nitrate and hypoxanthine as sole nitrogen sources be restored by sodium molybdate (Table 6). Molybdate had no effect on the other nar mutants.

Cytochrome spectra. In Pseudomonas aeruginosa some of the cytochromes are involved in nitrate or nitrite respiration. Purified nitrate reductase has been found to contain a $c$ type cytochrome (Fewson \& Nicholas, I96r). Yamanaka \& Okunuki (I963) demonstrated cytochrome oxidase and nitrite reductase in the same enzyme complex. This complex is a haemoprotein with both haem $c$ and $d$ groups. Newton (I969) and Lam \& Nicholas (I969) observed the same in Micrococcus denitrificans. In P. stutzeri (Kodama, 1970) and in Alcaligenes faecalis (Iwasaki \& Matsubara, I97I) too, the $c d$ haemoproteins have nitrite reductase activity.

Wild-type bacteria, grown semi-anaerobically in the presence of nitrate, contained cytochrome $c$ with absorption bands at 522 and $552 \mathrm{~nm}$, cytochrome $b$ (530 and $560 \mathrm{~nm}$ ) and cytochrome $d(465$ and $625 \mathrm{~nm})$. In the cytochrome spectra of nir mutants the bands at 465 
Table 5. Specific activity of nitrate reductase in cell-free extracts of a wild-type strain and a nar D mutant of Pseudomonas aeruginosa after anaerobic growth in the presence or absence of sodium molybdate

$\begin{array}{lcc} & \begin{array}{c}\text { Nitrate reductase } \\ (\mu \text { mol nitrite/min/mg protein })\end{array} \\ \text { Strain } & \begin{array}{c}\text { With molybdate } \\ \left(5 \times 10^{-4} \mathrm{M}\right)\end{array} & \begin{array}{c}\text { Without } \\ \text { molybdate }\end{array} \\ \text { S840 wild-type } & 0.56 & 0.60 \\ \text { SI 234 nar } D & 0.38 & 0.006\end{array}$

Table 6. Growth of prototrophic nar mutants of Pseudomonas aeruginosa with nitrate or hypoxanthine as sole nitrogen sources, with or without sodium molybdate

\begin{tabular}{|c|c|c|c|c|}
\hline \multirow[b]{3}{*}{ Strain } & \multicolumn{2}{|c|}{ Without molybdate } & \multicolumn{2}{|c|}{ With molybdate $\left(5 \times 10^{-4} \mathrm{M}\right)$} \\
\hline & $\begin{array}{c}\text { Nitrate } \\
\left(5 \times 10^{-2} \mathrm{M}\right)\end{array}$ & $\begin{array}{l}\text { Hypoxanthine } \\
\left(2 \cdot 2 \times 10^{-3} \mathrm{M}\right)\end{array}$ & $\begin{array}{c}\text { Nitrate } \\
\left(5 \times 10^{-2} \mathrm{M}\right)\end{array}$ & $\begin{array}{l}\text { Hypoxanthine } \\
\left(2.2 \times 10^{-3} \mathrm{M}\right)\end{array}$ \\
\hline & & & & \\
\hline s838 wild-type & + & + & + & + \\
\hline SII 30 nar $A$ & - & + & - & + \\
\hline SII33 narC & + & + & + & + \\
\hline SI $234 \operatorname{nar} D$ & - & - & + & + \\
\hline SI 24I narE & - & - & - & - \\
\hline SII 35 nar $B$ & - & - & - & - \\
\hline
\end{tabular}

and $625 \mathrm{~nm}$ were absent, possibly due to lack of haem $d$. The cytochrome spectra of the nar mutants were normal. Nitrate or nitrite was able to oxidize the cytochrome system in wild-type bacteria but not so well as oxygen; neither compound could oxidize the cytochrome systems of the nir mutants. Unexpectedly the nar mutants resembled the wild-type, possibly because a little nitrate reductase remained in these mutants.

Cytochrome oxidase activities in aerobically grown wild-type and nir mutants were the same $(3.5 \mathrm{nmol}$ oxygen consumed $/ \mathrm{min} / \mathrm{mg}$ protein). In wild-type bacteria grown semianaerobically in the presence of nitrate, cytochrome oxidase activity increased to $7 \mathrm{nmol}$ oxygen $/ \mathrm{min} / \mathrm{mg}$ protein. Nir mutants did not show this increase.

Ana mutants. These possessed both nitrate and nitrite reductase activity (van Hartingsveldt et al. I97I). To confirm that their nitrate respiratory system was normal they were cultured with poor aeration and limited amounts of nitrate. The results (Fig. 2) were as for the wild-type (van Hartingsveldt et al. 197I). Accumulation of nitrite in the medium started when the oxygen tension had become almost zero. The nitrite concentration in the medium reached a maximum and then gradually decreased to zero. Therefore nitrate and nitrite reduction must be normal in these mutants. The cytochrome spectra and the oxidation of the cytochrome system by nitrate or nitrite were the same as in the wild-type.

Aer mutants. In the aer mutants aerobic growth did not occur even in the presence of nitrate. Only oxygen tensions not in excess of about $4 \%$ allowed growth with nitrate on plates. Stationary-phase bacteria obtained after anaerobic growth with nitrate consumed oxygen when incubated with glucose, succinate or pyruvate at about the same rate as the wild-type. With the aer mutant SI 276 oxygen uptake with glucose amounted to I I $\mathrm{nmol} / \mathrm{min} / \mathrm{mg}$ protein, with succinate $59 \mathrm{nmol}$ and with pyruvate $37 \mathrm{nmol}$. NADH oxidase activity in stationary-phase bacteria of these mutants was 59 , which exceeds the activity of the wildtype by about $50 \%$. 


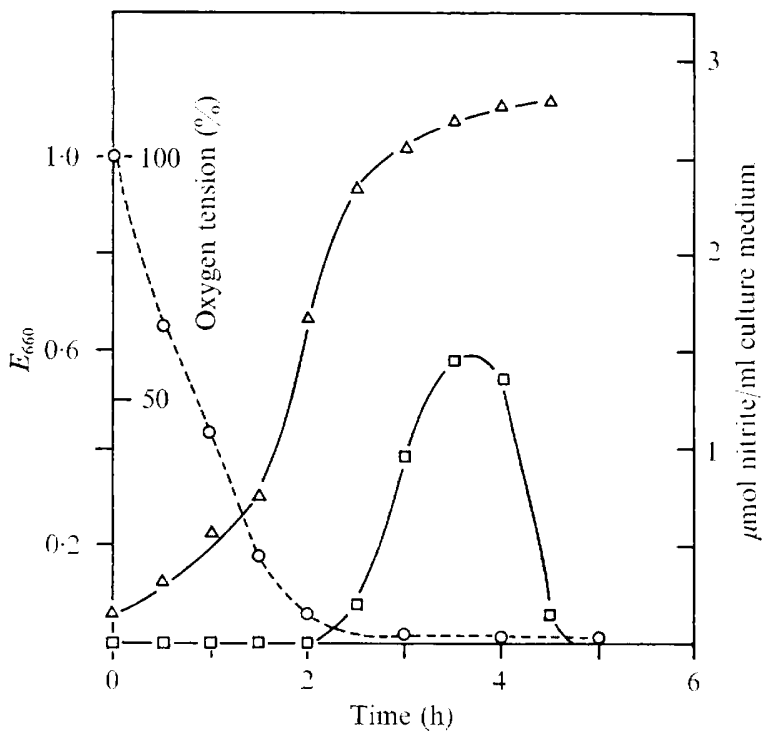

Fig. 2. Formation and consumption of nitrite during growth of Pseudomonas aeruginosa strain sio62 an $a B$ in NB with a limited concentration of $\mathrm{KNO}_{3}(0.05 \%)$ and under low oxygen tension. The oxygen tension at the start of the experiment is arbitrarily called $100 \%$. Growth is given as the extinction at $660 \mathrm{~nm}$. The amount of nitrite is expressed as $\mu \mathrm{mol} / \mathrm{ml}$ culture medium. $\bigcirc$, Oxygen tension; $\triangle$, growth; $\square$, concentration of nitrite in the medium.

\section{DISCUSSION}

The provisional map positions of the genes affecting anaerobic growth with nitrate in Pseudomonas aeruginosa, described by van Hartingsveldt et al. (197I), have been supplemented and confirmed by interrupted mating studies. In these experiments the time of entry of several genes has been determined. The difficulties of this method, resulting from low frequency of recombination (Loutit, 1969), were partially overcome by using less diluted mixtures of mating bacteria. The number of mating pairs formed on the plate was low and did not disturb the results. The distal genes $\operatorname{nar} A$, $\operatorname{nar} D$, nir $D$ and $\operatorname{nir} E$ were not mapped precisely because the conjugation system of $P$. aeruginosa is not as effective as that of Escherichia coli. No Hfr strains have yet been found, and donor strains with origins other than of the $\mathrm{FP}^{+}$strain used (Loutit, Pearce \& Marinus, I968; Stanisich \& Holloway, 1969) are not available. Some of the R-factors able to transfer chromosomal material from different points (Stanisich \& Holloway, 1971) might be useful to map late genes more precisely. Both Loutit (1969) and Stanisich \& Holloway (1969) proposed two linkage groups in P. aeruginosa. As our distal genes did not show linkage with genes of linkage group II, nor with met-9 of group I (Fig. I), no conclusion was drawn regarding the group in which they were located. The linkage data for $n a r B$ and $n a r C$ with $l e u-I$, all entering at about $45 \mathrm{~min}$, suggested the gene order leu-I narC narB. The location of anaB (nirC) and of aer is not known.

In Pseudomonas aeruginosa, as in a number of Enterobacteriaceae, several genes are involved in the reduction of nitrate to nitrite. At least five nar genes were found. Four (nar $A$, $B, D$ and $E$ ) have pleiotropic effects, as have most of the chl mutations in Escherichia coli (Piéchaud et al. 1967), Salmonella typhimurium (Stouthamer, 1969) and in Klebsiella aerogenes (Stouthamer, 1967a, $b$; Stouthamer et $a l$. I967). In $n a r B, D$ and $E$ a molybdenum-containing 
co-factor, common to dissimilatory and assimilatory nitrate reductase and xanthine dehydrogenase, might be affected (Arst et al. 1970). In nar D mutants molybdenum might not be incorporated in this factor or converted into the proper redox state (Glaser \& DeMoss, I97 I). There is some evidence that a defect in the uptake of molybdenum in the nar D mutants can be ruled out (unpublished results). A defect in a part common to both dissimilatory and assimilatory nitrate reductase might account for the nar $A$ mutation. This agrees with the view that in $K$. aerogenes the assimilatory and dissimilatory nitrate reductase are the same protein, but present in different complexes (Van'T Riet et al. 1968). In the narC strains, which lacked only dissimilatory nitrate reductase, a defect might exist in the assembly of the membrane and enzymatic components of the enzyme complex, as has been reported for chlA and chlB mutants of E. coli (Azoulay, Puig \& Couchoud-Beaumont, I969). A defect in a membrane component is also possible.

The cytochrome oxidase described by Yamanaka et al. (1963), which contains both a haem $c$ and a haem $d$ group, was only induced in the presence of nitrate in Pseudonomas aeruginosa. Furthermore, a second cytochrome oxidase, without nitrite reductase activity, was present under several conditions (Azoulay, I964; Azoulay \& Couchoud-Beaumont, 1965). The high cytochrome oxidase activity of the wild-type strain after semi-anaerobic culturing with nitrate might result from the presence of both cytochrome oxidases under these conditions. The low activity of cytochrome oxidase in the nir mutants, grown under the same conditions, must be attributed to the absence of the enzyme described by Yamanaka et al. (I963), resulting from lack of haem $d$.

Both in the aer and ana mutants the cytochrome spectra, nitrate and nitrite reductase activity (van Hartingsveldt et al. 1971) and respiration with oxygen were normal. Consequently the absence of aerobic growth in the aer mutants and of anaerobic growth in the ana mutants are probably not due to a defect in the energy generating system although defective coupling factors cannot be excluded. Further work is required to explain the defects in these mutants.

The technical assistance of Miss F. A. De Meijere and Mr M. V. M. Lafleur is gratefully acknowledged.

\section{REFERENCES}

Arst, H. N., Jun., MaCDonald, D. W. \& Cove, D. J. (1970). Molybdate metabolism in Aspergillus nidulans. I. Mutations affecting nitrate reductase and/or xanthine dehydrogenase. Molecular and General Genetics I08, I 29-I 45 .

Azoulay, E. (I964). Influence des conditions de culture sur la respiration de Pseudomonas aeruginosa. Biochimica et biophysica acta 92, 458-464.

Azoulay, E. \& Couchoud-Beaumont, P. (1965). Étude de la cytochrome-oxidase de Pseudomonas aeruginosa. Biochimica et biophysica acta $\mathbf{1} 10,30 \mathrm{I}-3 \mathrm{I} \mathrm{I}$.

Azoulay, E., Puig, J. \& Couchoud-Beaumont, P. (i969). Étude des mutants chlorate-résistants chez Escherichia coli KI2. I. Reconstitution in vitro de l'activité-réductase particulaire chez Escherichia coli $\mathrm{K} \mathrm{I}$ 2. Biochimica et biophysica acta $\mathbf{1 7}, 238-252$.

Fewson, C. A. \& Nicholas, D. J. D. (196I). Nitrate reductase from Pseudomonas aeruginosa. Biochimica et biophysica acta 49, 335-349.

Glaser, J. H. \& DeMoss, J. A. (I97I). Phenotypic restoration of nitrate reductase activity in $c h l D$ mutants of Escherichia coli. Journal of Bacteriology 108, 854-860.

van Hartingsveldt, J., Marinus, M. G. \& Stouthamer, A. H. (I97I). Mutants of Pseudomonas aeruginosa blocked in nitrate or nitrate dissimilation. Genetics 67, 469-482.

Holloway, B. W., Monk, M., Hodgins, L. \& Fargie, B. (1962). Effects of radiation on transduction in Pseudomonas aeruginosa. Virology $\mathbf{1 8}, 89-94$.

IWASAKI, H. \& Matsubara, T. (1971). Cytochrome $c-557$ (551) and cytochrome $c d$ of Alcaligenes faecalis. Journal of Biochemistry 69, 847-857. 
Ketchum, P. A., Cambier, H. Y., Frazier, W. A., III, Madansky, C. H. \& Nason, A. (i970). In vitro assembly of Neurospora assimilatory nitrate reductase from protein subunits of a Neurospora mutant and the xanthine oxidizing or aldehyde oxidase system of higher animals. Proceedings of the National Academy of Sciences of the United States of America 66, 10 I6-1023.

KoDAMA, T. (1970). Effects of growth conditions on formation of the cytochrome system of a denitrifying bacterium, Pseudomonas stutzeri. Plant and Cell Physiology rr, 23 I-239.

LAM, Y. \& Nicholas, D. J. D. (I969). A nitrite reductase with cytochrome oxidase activity from Micrococcus denitrificans. Biochimica et biophysica acta $\mathbf{1 8 0}, 459-472$.

LESTER, R. L. \& DeMoss, J. A. (I97I). Effects of molybdate and selenite on formate and nitrate metabolism in Escherichia coli. Journal of Bacteriology ro5, 1006-1014.

Loutit, J. S. (1969). Investigation of the mating system of Pseudomonas aeruginosa strain I. IV. Mapping of distal markers. Genetical Research $\mathbf{1 3}, 9 \mathrm{I}-98$.

LoutiT, J. S. \& DAvis, P. F. (1970). Mutants of Pseudomonas aeruginosa strain I with unusual acetohydroxyacid synthetase enzymes. Biochimica et biophysica acta 222, 222-225.

Loutit, J. S., Pearce, L. E. \& Marinus, M. G. (I968). Investigation of the mating system of Pseudomonas aeruginosa strain I. I. Kinetic studies. Genetical Research 12, 29-36.

Lowry, O. H., Rosebrough, N. J., Farr, A. L. \& Randell, R. J. (I95I). Protein measurement with the Folin reagent. Journal of Biological Chemistry I93, 265-275.

Newton, N. (1969). The two-haem nitrite reductase of Micrococcus denitrificans. Biochimica et biophysica acta $185,316-331$.

Pateman, J. A., Cove, D. J., Rever, B. M. \& Roberts, D. B. (I964). A common cofactor for nitrate reductase and xanthine dehydrogenase which also regulates the synthesis of nitrate reductase. Nature, London 201, 58-60.

Piéchaud, M., Puig, J., Pichinoty, F., Azoulay, E. \& Le Minor, L. (1967). Mutations affectant la nitrate réductase A et d'autre enzymes bactériennes d'oxydoréduction. Etude préliminaire. Annales de l'Institut Pasteur I12, 24-37.

Stanier, R. Y., Palleroni, N. J. \& Douderoff, M. (1966). The aerobic pseudomonads: a taxonomic study. Journal of General Microbiology 43, I 59-27I.

Stanisich, V. A. \& Holloway, B. W. (I97I). Chromosome transfer in Pseudomonas aeruginosa mediated by R factors. Genetical Research $17,169-172$.

Stanisich, V. A. \& Holloway, B. W. (I969). Conjugation in Pseudomonas aeruginosa. Genetics 6r, 327-339.

STOUTHAMER, A. H. (1967a). Nitrate reduction in Aerobacter aerogenes. I. Isolation and properties of mutant strains blocked in nitrate assimilation and resistant against chlorate. Archiv für Mikrobiologie 56, 68-75.

Stouthamer, A. H. (I967b). Nitrate reduction in Aerobacter aerogenes. II. Characterization of mutants blocked in the reduction of nitrate and chlorate. Archiv für Mikrobiologie 56, 76-80.

Stouthamer, A. H. (1969). A genetical and biochemical study of chlorate-resistant mutants of Salmonella typhimurium. Antonie van Leeuwenhoek 35, 505-52 I.

Stouthamer, A. H., Bettenhausen, C., van Hartingsveldt, J., Van'T Riet, J. \& Planta, R. J. (i967). Nitrate reduction in Aerobacter aerogenes. III. Nitrate reduction, chlorate resistance and formate metabolism in mutant strains. Archiv für Mikrobiologie 58, 228-247.

Umbreit, W. W., Burris, R. H. \& Stauffer, J. F. (I964). Manometric techniques, 4th edn, pp. I62-165. Minneapolis: Burgess Publishing Company.

Van'T Riet, J., Stouthamer, A. H. \& Planta, R. J. (I968). Regulation of nitrate assimilation and nitrate respiration in Aerobacter aerogenes. Journal of Bacteriology 96, 1455-1464.

WOLDENDORP, J. W. (1963). The influence of living plants on denitrification. Ph.D. Thesis, Landbouwhoge School, Wageningen, The Netherlands.

Yamanaka, T. \& Okunuki, K. (I963). Crystalline Pseudomonas cytochrome oxidase. I. Enzymic properties with special reference to the biological specificity. Biochimica et biophysica acta 67, 379-393.

YamanaKa, T., OTA, A. \& OKunUKI, K. (196I). A nitrite reducing system reconstructed with purified cytochrome components of Pseudomonas aeruginosa. Biochimica et biophysica acta 53, 294-308. 